\title{
Technical note: A simple theoretical model framework to describe plant stomatal "sluggishness" in response to elevated ozone concentrations
}

\author{
Chris Huntingford ${ }^{1}$, Rebecca J. Oliver ${ }^{1}$, Lina M. Mercado ${ }^{2,1}$, and Stephen Sitch ${ }^{2}$ \\ ${ }^{1}$ Centre for Ecology and Hydrology, Benson Lane, Wallingford, Oxfordshire, OX10 8BB, UK \\ ${ }^{2}$ College of Life and Environmental Sciences, University of Exeter, Amory Building, Rennes Drive, Exeter, EX4 4RJ, UK
}

Correspondence: Chris Huntingford (chg@ceh.ac.uk)

Received: 25 April 2018 - Discussion started: 7 May 2018

Revised: 31 July 2018 - Accepted: 24 August 2018 - Published: 12 September 2018

\begin{abstract}
Elevated levels of tropospheric ozone, $\mathrm{O}_{3}$, cause damage to terrestrial vegetation, affecting leaf stomatal functioning and reducing photosynthesis. Climatic impacts under future raised atmospheric greenhouse gas (GHG) concentrations will also impact on the net primary productivity (NPP) of vegetation, which might for instance alter viability of some crops. Together, ozone damage and climate change may adjust the current ability of terrestrial vegetation to offset a significant fraction of carbon dioxide $\left(\mathrm{CO}_{2}\right)$ emissions. Climate impacts on the land surface are well studied, but arguably large-scale modelling of raised surface level $\mathrm{O}_{3}$ effects is less advanced. To date most models representing ozone damage use either $\mathrm{O}_{3}$ concentration or, more recently, flux-uptake-related reduction of stomatal opening, estimating suppressed land-atmosphere water and $\mathrm{CO}_{2}$ fluxes. However there is evidence that, for some species, $\mathrm{O}_{3}$ damage can also cause an inertial "sluggishness" of stomatal response to changing surface meteorological conditions. In some circumstances (e.g. droughts), this loss of stomata control can cause them to be more open than without ozone interference. To both aid model development and provide empiricists with a system on to which measurements can be mapped, we present a parameter-sparse framework specifically designed to capture sluggishness. This contains a single time-delay parameter $\tau_{\mathrm{O}_{3}}$, characterizing the timescale for stomata to catch up with the level of opening they would have without damage. The larger the value of this parameter, the more sluggish the modelled stomatal response. Through variation of $\tau_{\mathrm{O}_{3}}$, we find it is possible to have qualitatively similar responses to factorial experiments with and without raised $\mathrm{O}_{3}$, when comparing to reported measurement time series pre-
\end{abstract}

sented in the literature. This low-parameter approach lends itself to the inclusion of ozone-induced inertial effects being incorporated in the terrestrial vegetation component of Earth system models (ESMs).

\section{Introduction}

Anthropogenic emissions from industrial processes, transport and biomass burning are increasing background levels of surface ozone, $\mathrm{O}_{3}\left(\mathrm{~mol} \mathrm{~mol}^{-1}\right)$ (Vingarzan, 2004). There is much evidence this adjusts the stomatal opening of terrestrial vegetation, and so influencing land-atmosphere exchanges of water and carbon both globally and locally (Ainsworth et al., 2012; Wittig et al., 2007, 2009; Mills et al., 2016). This may reduce the ability of vegetation to photosynthesize, which at the global scale is a concern as it may lower the current fraction of $\mathrm{CO}_{2}$ emissions the land draws down (Felzer et al., 2005; Sitch et al., 2007; Lombardozzi et al., 2015). At more local-to-regional scales, ozone-induced damage could affect crop yields and hence potentially food security Ainsworth et al. (2012); Anav et al. (2011); Avnery et al. (2011); Tai et al. (2014).

Increasingly though, for some plant species the situation is discovered to be more complex. A growing number of species are found to show increased stomatal opening and/or delayed stomatal opening, termed stomatal sluggishness, caused by raised concentrations of ozone (Mills et al., 2016). Under stressed conditions, such as drought, the mechanism has been linked to ozone interfering with the 
hormonal signalling pathway abscisic acid (ABA) (Wilkinson and Davies, 2009, 2010; Mills et al., 2009). ABA is used by plants to communicate to stomata the need to reduce opening in the presence of growing abiotic stress conditions. Specifically, elevated ozone stimulates ethylene production which prevents ABA from otherwise closing stomata (Wilkinson and Davies, 2009, 2010). Loss of stomatal control is observed in response to a range of environmental factors, including drought (Wilkinson and Davies, 2009, 2010; Mills et al., 2009; Hayes et al., 2012; Wagg et al., 2013), high light (Paoletti and Grulke, 2010; Hoshika et al., 2012b; Wagg et al., 2013) and high vapour pressure deficit (Grulke et al., 2007). The ABA signalling pathway mediates stomatal responses to many of these stress factors, as has been found particularly in drought conditions. It is therefore likely to play a role in controlling stomatal responses to ozone under fluctuating environmental conditions.

Ozone-induced sluggishness can have the opposite effect to that generally associated with $\mathrm{O}_{3}$ damage. In some circumstances stomata are more open than without $\mathrm{O}_{3}$ influence. Ozone-induced sluggish behaviour that delays stomatal closure means affected plants create a positive feedback whereby they receive a higher $\mathrm{O}_{3}$ flux with greater $\mathrm{O}_{3}$ damage resulting. Impacted plants could also lose more water, and if this occurs during drought episodes for example, this may exacerbate soil moisture deficits, in turn affecting net primary productivity (NPP). Hence there are implications for water use, crop yields and food security (Sun et al., 2012; Tai et al., 2014; Van Dingenen et al., 2009).

At the regional scale, McLaughlin et al. (2007a, b) and Sun et al. (2012) provide field evidence of increased transpiration and reduced streamflow in forests. This is attributed to a sluggish stomatal response to ambient levels of $\mathrm{O}_{3}$. This could increase the frequency and severity of droughts, then suppressing forest productivity and add to any direct $\mathrm{O}_{3}$ inhibition of photosynthetic capacity. However, in contrast, Hoshika et al. (2012a) found that despite sluggish stomatal control in trees exposed to $\mathrm{O}_{3}$, whole tree water use reduced due to lower gas exchange and premature shedding of injured leaves. The literature suggests that sluggish stomata response to $\mathrm{O}_{3}$ is not ubiquitous (Mills et al., 2016; Wittig et al., 2007); which species respond this way and under what conditions requires understanding. For species affected, significant impacts on watershed hydrology and carbon sequestration are possible. The extent of any stomatal inertial response is likely dependent on the magnitude and cumulated time of exposure to raised $\mathrm{O}_{3}$, suggesting the importance of experiments to analyse this and that require operation over long time series such as full growing seasons.

Most large-scale terrestrial models represent raised tropospheric ozone concentrations as detrimental to photosynthesis, inducing extra stomatal closure (Wittig et al., 2007). For instance, the JULES (Joint UK Land Environment Simulator) model uses a flux-gradient approach to describe simulated plant $\mathrm{O}_{3}$ damage (Sitch et al., 2007; Clark et al., 2011).
The model is parameterized to reduce photosynthesis in response to accumulated $\mathrm{O}_{3}$ uptake, and because in JULES this processes is coupled to stomatal conductance, that also decreases. This has similarities to how ozone damage representation has been introduced by Franz et al. (2017) to the OCN land model Zaehle and Friend (2010). Lombardozzi et al. (2012), for the CLM (Community Land Model), decouple photosynthesis and stomatal conductance so that raised surface $\mathrm{O}_{3}$ levels reduce carbon assimilation disproportionately more than transpiration. A first attempt to numerically emulate the sluggish feature of higher stomatal opening is by Hoshika et al. (2015). They modulate the multi-layer atmosphere-soil-vegetation (SOLVEG) terrestrial model so the minimum stomatal opening in the Ball-Woodrow-Berry model, $g_{\min }\left(\mathrm{m} \mathrm{s}^{-1}\right)$, increases for higher cumulative $\mathrm{O}_{3}$ exposure. This potentially raises transpiration losses.

Geographically extensive projections of ozone impacts on the land surface response need understanding within the context of other large-scale changes affecting terrestrial ecosystems. These include the direct physiological effect of raised $\mathrm{CO}_{2}$ through fossil fuel burning, the impact of climate change due to raised $\mathrm{CO}_{2}$ and other greenhouse gases (GHGs), and aerosols adjusting the composition of downward shortwave radiation (Huntingford et al., 2011). Even if an emissions trajectory is followed that achieves global warming stabilized at $2{ }^{\circ} \mathrm{C}$ above pre-industrial levels, general near-surface warming over land will be higher (Huntingford and Mercado, 2016). Therefore even moderate levels of global warming could have strong influences on terrestrial vegetation, and in this situation any additional ozone-induced changes need to be described. Earth system models (ESMs) are the main tools to describe the effect on climate of raised atmospheric GHGs, and interactions and feedbacks on global biogeochemical cycles. Such models contain a land surface component, e.g. the JULES model (Clark et al., 2011) within the HadGEM2-ES ESM (Jones et al., 2011). HadGEM2-ES ESM carries ozone as an atmospheric tracer, to which JULES responds Sitch et al. (2007). ESMs contribute to global model databases, most recently the fifth phase of the Coupled Model Intercomparison Project, CMIP5 (Taylor et al., 2012), which inform the United Nations Intergovernmental Panel on Climate Change reports (e.g., IPCC, 2013). If a substantial fraction of vegetation responses to elevated tropospheric ozone contain stomata sluggishness, this requires implementation in large-scale terrestrial vegetation models and ESMs to assess global implications. Any influence on terrestrial carbon stores is important for attribution and understanding of recent trends in the land carbon sink (e.g., Le Quéré et al., 2018).

Opportunities exist to incorporate inertia within mechanistic equations. Direct ozone interactions with abscisic acid may be modelled, if a suggestion is fulfilled that the ABA hormone be included in large-scale land models (Huntingford et al., 2015). However to proceed before then, a more empirically based description is required. By definition, 
stomatal sluggishness implies a timescale exists, describing the delay behind a state without ozone damage. We call this timescale $\tau_{\mathrm{O}_{3}}(\mathrm{~s})$.

\section{Sluggishness parameter $\tau_{\mathrm{O}_{3}}$ and modelled stomatal opening}

Proposed is a simple and minimal mathematical description of sluggishness. We first set the time-evolving leaf-level stomatal opening that would occur without ozone damage as $g_{1}(t)\left(\mathrm{m} \mathrm{s}^{-1}\right)$. This is assumed to respond to the standard drivers of temperature $T(\mathrm{~K})$, light level (i.e. photosynthetic active radiation $I_{\mathrm{P}}\left(\mathrm{W} \mathrm{m}^{-2}\right)$ ), vapour pressure deficit (VPD $(\mathrm{kPa}))$ and soil moisture status $\theta\left(\mathrm{kg}\right.$ water $\left.(\mathrm{kg} \text { soil })^{-1}\right)$. A second variable is defined as the stomatal opening with additional ozone-induced sluggishness and named $g_{1, \operatorname{slug}}(t)$ $\left(\mathrm{m} \mathrm{s}^{-1}\right)$. Sluggishness is characterized by a single new parameter $\tau_{\mathrm{O}_{3}}$ (s), representing the timescale of how long ozone-damaged stomata take to "catch up" with the level of opening without $\mathrm{O}_{3}$ influence, i.e. $g_{1}=g_{1}\left(T, I_{\mathrm{P}}\right.$, VPD, $\left.\theta\right)$. This leads to the ordinary differential equation, for the rate of change of $g_{1 \text {,slug }}$ with respect to time $t$ (s), as

$\frac{\mathrm{d} g_{1, \text { slug }}}{\mathrm{d} t}=-\frac{g_{1, \text { slug }}-g_{1}}{\tau_{\mathrm{O}_{3}}}$.

For this technical note, two illustrative sets of solutions to Eq. (1) are considered. Setting $t_{\text {day }}=86400$ (s) as the number of seconds in a day, the sluggishness effects for a timescale less than 1 day, with $\tau_{\mathrm{O}_{3}} / t_{\text {day }}=0.25$, are first modelled. Then a second set, corresponding to a more sluggish timescale that is significantly greater than 1 day, are considered, with $\tau_{\mathrm{O}_{3}} / t_{\text {day }}=6$. These are shown, respectively, as the magenta curves in the left-hand and right-hand columns of Fig. 1. The green curves are with no $\mathrm{O}_{3}$ sluggish damage, showing identical curves for $g_{1}$ between the two diagram columns. The background "sluggish-free" curves for $g_{1}$ are described in Appendix A, and they broadly correspond to three cases as daily variability for (i) well-watered vegetation, (ii) a period of increasing drought conditions and (iii) recovery from drought. These correspond to the top, middle and bottom rows respectively of Fig. 1 .

The simulations are summarized as follows. In the wellwatered case (top row), for $\tau_{\mathrm{O}_{3}} / t_{\text {day }}=0.25$ there remains a sizeable diurnal cycle in the ozone-damaged stomatal conductance $g_{1, \text { slug. For }} \tau_{\mathrm{O}_{3}} / t_{\text {day }}=6$, almost all within-day variation is lost and stomata remain open throughout the nighttime periods. For drying conditions (middle panels), again for the smaller $\tau_{\mathrm{O}_{3}}$ case, there remains subdiurnal variability, and the downward trend is similar between damaged and undamaged stomata. However, for larger $\tau_{\mathrm{O}_{3}}$, the solution to Eq. (1) is such that the larger inertia makes stomata eventually more open than at any point during the diurnal cycle of those that are undamaged. This scenario is starting to receive particular interest, with emerging evidence that ozone damage can under some circumstances cause excessive opening of stomata. In the bottom row, the lower $\tau_{\mathrm{O}_{3}}$ example (left) shows again delays at subdiurnal timescale, but the damaged stomata retain capability to open more as conditions become more favourable. For the higher $\tau_{\mathrm{O}_{3}}$ case, there is only minimal ability to keep up with increases in opening by the modelled undamaged stomata.

Observational evidence of different levels of sluggishness suggests that these are a function of accumulated exposure (e.g., Hoshika et al., 2015). For existing models of $\mathrm{O}_{3}$ damage to stomata, a level exists and only above which damage occurs to account for the ability of vegetation to detoxify low levels of ozone. In Sitch et al. (2007) for instance, that threshold is a level of ozone flux in to vegetation. This implies that the evolution of $\tau_{\mathrm{O}_{3}}$, possibly dependent on time since the start of the growth season, $t_{\mathrm{g} \text {,start }}$ (s), can be described by two parameters. The first is a critical threshold above which damage occurs, as flux $F_{\mathrm{O}_{3, \text { crit }}}$ $\left(\right.$ nmol m${ }^{-2} \mathrm{~s}^{-1}$ ) (or concentration $\mathrm{O}_{3 \text {, crit }}\left(\mathrm{mol} \mathrm{mol}^{-1}\right)$ ). The second linearly relates time spent over the threshold to the amount of sluggishness, expressed by changes to $\tau_{\mathrm{O}_{3}}$. Hence $\tau_{\mathrm{O}_{3}}(t)=b \int_{t_{\mathrm{g}, \text { start }}}^{t} \max \left[F_{\mathrm{O}_{3}}-F_{\mathrm{O}_{3, \text { crit }}}, 0\right] \mathrm{d} t$ or $\tau_{\mathrm{O}_{3}}(t)=$ $b \int_{t_{\mathrm{g}, \text { start }}}^{t} \max \left[\mathrm{O}_{3}-\mathrm{O}_{3, \text { crit }}, 0\right] \mathrm{d} t$. This second parameter $b$ has units of either $\mathrm{s}\left[\mathrm{nmol} \mathrm{m}{ }^{-2}\right]^{-1}$ or $\left[\mathrm{mol} \mathrm{mol}^{-1}\right]^{-1}$.

\section{Discussion}

There is evidence in the literature that some features of Fig. 1 can be seen in measurements. Our two representative values of $\tau_{\mathrm{O}_{3}}$ are guided by the experimental measurements presented for Siebold's beech (Hoshika et al., 2012b) and for grassland (Hayes et al., 2012). In the former, after approximately two months at double ambient ozone concentration (at well-watered conditions), imposed oscillations of light levels on timescale order hours cause variations in stomatal opening which have a slight lag compared to equivalent experiments at ambient $\mathrm{O}_{3}$ levels. This is analogous to our smaller $\tau_{\mathrm{O}_{3}} / t_{\text {day }}$ values of sub-daily magnitude, seen by comparison of Fig. 2a of Hoshika et al. (2012b) with Fig. 1a. Similar curves are observed for beans, in Fig. 1 of Paoletti and Grulke (2010). In the grassland experiments of Hayes et al. (2012), analysis is made of well-watered and reducedwatered (i.e. drought experiments) and for different $\mathrm{O}_{3}$ concentration treatments. The notable feature in those experiments is that for very high $\mathrm{O}_{3}$ levels (order $90 \mathrm{nmol} \mathrm{mol}^{-1}$ ), then beyond nine weeks at that level and in the droughtinduced case, the stomata are almost as wide open as the well-watered example. This suggests a long-term broad inability to respond to changing conditions, and so in-keeping with our high sluggish $\tau_{\mathrm{O}_{3}} / t_{\text {day }}$ value of much greater than 1 day. That is, this near-complete loss of ability to respond to emerging drought conditions has similarities between Fig. 4c 

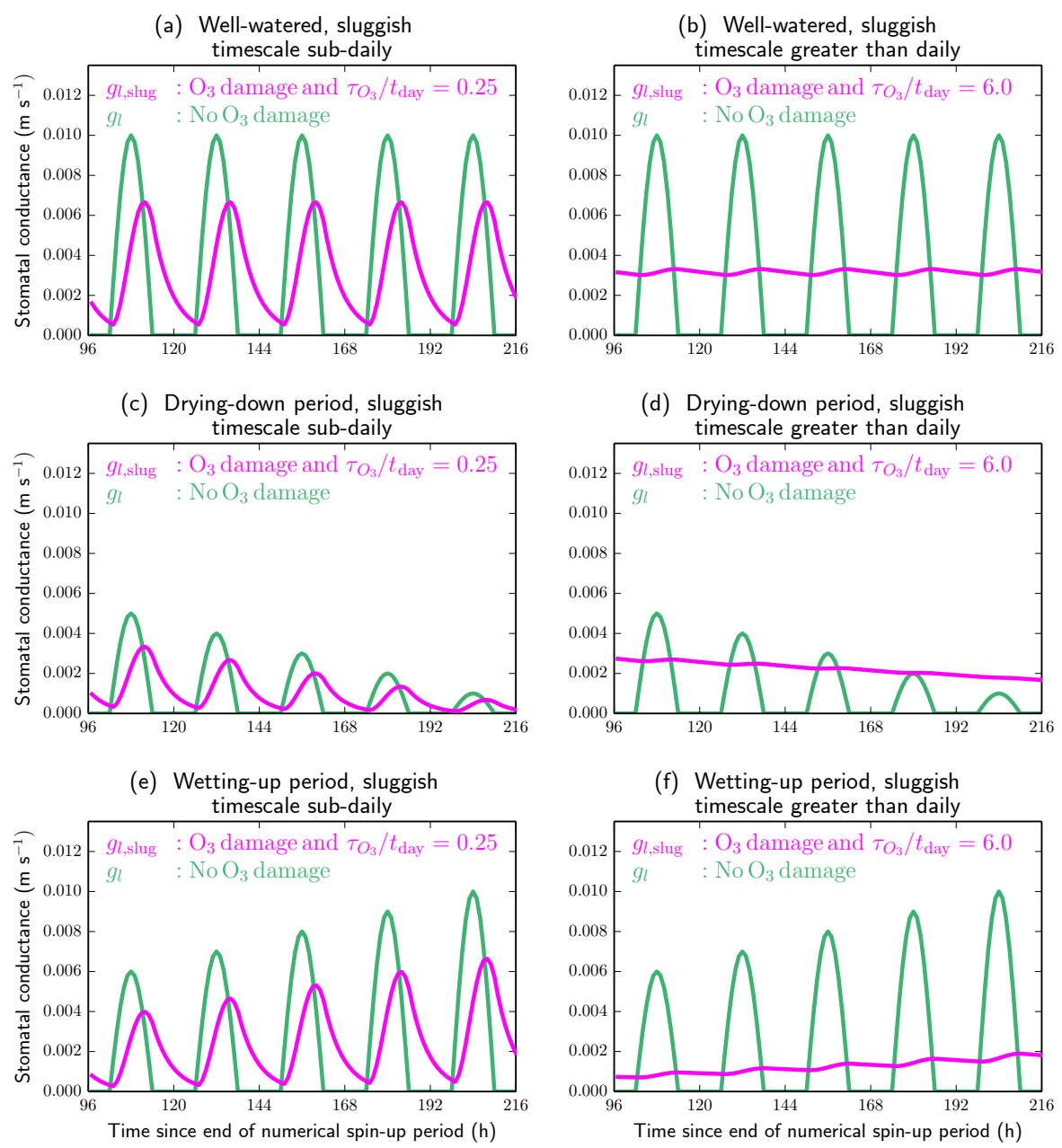

Figure 1. The effect of low (a, c, e) and high (b, d, f) levels of stomatal sluggishness. Calculations for stomatal conductance correspond to well-watered conditions $(\mathbf{a}, \mathbf{b})$, entering a period of drought $(\mathbf{c}, \mathbf{d})$ and recovery from drought $(\mathbf{e}, \mathbf{f})$. Simulations are for nine $24 \mathrm{~h}$ periods, with the last five shown. Green curves are stomatal conductance without ozone effects, and magenta curves are with sluggishness. Appendix A details the modelling framework and driving conditions leading to these curves.

of Hoshika et al. (2012b) and the middle row, right-hand panel of our Fig. 1 (i.e. Fig. 1d).

Our mathematical framework of Eq. (1) and solution for two representative $\tau_{\mathrm{O}_{3}}$ values raises a set of conjectures, issues and questions about the implications of stomatal sluggishness. This can aid in developing future measurement campaigns of ozone effects on stomatal conductance, to test the validity of Eq. (1) and then its parameterization if verified as an appropriate model.

For sluggishness at sub-daily periods $\tau_{\mathrm{O}_{3}} / t_{\text {day }}<1$, stom-

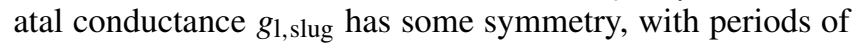
both larger and smaller opening, when compared to $g_{1}$. However, this may cause an asymmetry for photosynthetic activity, as there are frequently periods at night when sluggish stomata are open (left columns of Fig. 1) and when photosynthesis would not occur. Conversely daytime opening is often suppressed in $g_{1, \text { slug }}$, and so overall sluggish stomatal response will lower terrestrial carbon uptake. This is seen in Fig. 2b of Hoshika et al. (2012b). Hence when averaged over periods longer than 1 day, sluggishness will dampen overall draw-down of atmospheric $\mathrm{CO}_{2}$. This could cause a misattribution of effect, if measurements are made during daytime light periods only and with $\tau_{\mathrm{O}_{3}} / t_{\text {day }}<1$. This is because in the presence of stomatal sluggishness, and with measurements made only when stomata are less open than without $\mathrm{O}_{3}$ damage (i.e. no night measurements), it could be inferred that the more conventional non-sluggish overall closure descriptions of damage are valid. An open research question is whether stomata could have both responses. That is the commonly modelled ozone flux-based (or concentration-based) description that always reduces stomatal opening, as well as an additional inertial contribution.

With evidence that ozone damage can cause raised stomatal opening, in some circumstances and for some species, 
this is of concern during periods of approaching drought, high temperatures or both. Under severe ozone damage with $\tau_{\mathrm{O}_{3}} / t_{\text {day }} \gg 1$ and during "drying-down" periods, raised evapotranspiration through larger stomatal opening could trigger severe water stress. This may deplete soil moisture to levels that would not otherwise have been attained. This could cause wilting or initiate plant hydraulic failure through embolism or cavitation, with clear implications for crop viability and food security in regions that experience seasonal drought. More comprehensive characterization of $\mathrm{O}_{3}$ thresholds and length of time over them that could cause this situation is required. Furthermore, long-term (i.e. chronic) ozone influence on photosynthetic capability may alter terrestrial carbon stores and thus the global carbon cycle. The size of current uncertainty in the modelled global carbon cycle is large, reaching order $40 \%$ of that of the physical climate in terms of predicting expected future warming levels (Huntingford et al., 2009).

If the ABA signalling process plays a key role in linking tropospheric ozone levels to stomata sluggish effects, then careful analysis is needed of data from experimental examples of well-watered vegetation at high ozone levels. This is because high ABA concentrations generally increase during periods of soil moisture stress, to which stomata respond by lowering their opening. If, therefore, sluggishness is also observed during well-watered periods and hence for low ABA concentrations, then this suggests that additional mechanisms operate beyond this hormone in linking $\mathrm{O}_{3}$ concentrations to inertia of stomata.

Finally, the representation of general plant functional types (PFTs) in land surface models is evolving, and including a larger set of them (e.g. Harper et al., 2016) changes the JULES model from five basic PFTs to nine. In the event that comprehensive measurements show variations in sluggishness between species, then this could inform future PFT definitions - existing PFTs in large-scale land models may have to be split to accommodate different responses. For trees, for example, birch and oak are found to have high and low sensitivity in existing models of ozone-induced stomatal closure (Sitch et al., 2007). Hoshika et al. (2018) find similarly that sluggishness effects might be stronger in white birch than deciduous oak.

\section{Conclusions}

We present a simple first-order differential equation to characterize the observed "sluggish" response of modelled stomata to elevated levels of tropospheric ozone. The formulation is deliberately parameter-sparse, with a single parameter $\tau_{\mathrm{O}_{3}}$. This parameter represents a delay, characterizing the timescale required for ozone-damaged stomata to "catch up" with the value it would have without ozone-induced damage.

Through simple numerical examples we illustrate how, depending on circumstances, this equation can project stomata to be both more closed than they would otherwise be, and critically the opposite whereby sluggishness can provide a mechanism for additional opening. Stomata that are more open through ozone damage have been reported from observations, yet they are currently not routinely included in land surface response models. This is because most existing modelling schemes can only lower stomatal opening for raised $\mathrm{O}_{3}$ levels.

Targeted measurement campaigns may provide more detailed information on the appropriateness of our $\tau_{\mathrm{O}_{3}}$ formulation. This includes (a) whether this is a generic form for describing tropospheric ozone damage to vegetation (or alternatively, for instance, if the response may be nonlinear in $g_{1, \text { slug }}-g_{1}$ ), (b) how the $\tau_{\mathrm{O}_{3}}$ value depends on accumulated ozone exposure, or if there is a more complex dependence on $\mathrm{O}_{3}$ exposure history, and (c) if there is potential to map on to broad PFTs. However if our formulation is broadly valid, then "sluggish" effects can be implemented within largescale land surface models such as JULES (Clark et al., 2011) via our proposed Eq. (1). Furthermore, if valid, then eventual implementation in the large-scale terrestrial models of ESMs offers hope that the implications of sluggish stomata can be understood in the context of simultaneous changing climatic conditions, the global carbon cycle and varying tropospheric ozone levels, along with any feedbacks.

Code availability. Python code leading to Fig. 1 is available on request from Chris Huntingford (chg@ceh.ac.uk). 


\section{Appendix A: Parameters leading to illustrative Fig. 1}

The driving conditions leading to the illustrative simulations of Fig. 1 are as follows. In well-watered conditions, and without ozone damage influence, a daily maximum stomatal opening $g_{1, \max }$ is assumed invariant, at $0.01 \mathrm{~m} \mathrm{~s}^{-1}$. This is representative of midday values, under high sunlight levels and with well-watered conditions. This corresponds to the top row of Fig. 1. Sub-daily variability is then described as the part of a sinusoidal function when positive as

$g_{1}=g_{1, \max }(t) \times \max \left\{-\cos \left(\frac{2 \pi t}{t_{\text {day }}}\right), 0\right\}$.

"Drying-down" is represented by changing $g_{1, \max }$ on a daily basis, following a period of being well-watered at $0.01 \mathrm{~m} \mathrm{~s}^{-1}$. This occurs over 9 days, down to a minimum stomatal opening of $0.001 \mathrm{~m} \mathrm{~s}^{-1}$, falling by $0.001 \mathrm{~m} \mathrm{~s}^{-1}$ each day. This is the middle panels of Fig. 1. "Wetting-up" is described as following a period with low conductance of $0.001 \mathrm{~m} \mathrm{~s}^{-1}$, rising to $0.01 \mathrm{~m} \mathrm{~s}^{-1}$ over 9 days, the bottom panels of Fig. 1. These calculations of $g_{1}$ are the green curves throughout the diagram.
Equation (1) is then solved to calculate $g_{1, \text { slug }}(t)$, for the corresponding values in each diagram panel of $g_{1}$. This is with left panels of $\tau_{\mathrm{O}_{3}} / t_{\text {day }}=0.25$ and right panels of $\tau_{\mathrm{O}_{3}} / t_{\text {day }}=6.0$. As Eq. (1) is a non-equilibrium solution, then initial conditions are required. We do this numerically, by "spinning up" over 100 repeated initial days, which in the top and middle panels are well-watered with $g_{1, \max }=$ $0.01 \mathrm{~m} \mathrm{~s}^{-1}$, and bottom panels are drought conditions with $g_{1, \max }=0.001 \mathrm{~m} \mathrm{~s}^{-1}$. 
Author contributions. $\mathrm{CH}$ created the theoretical model, operated the numerical experiments and designed the paper. RJO, LMM and SS performed the literature review and placed the analysis in the context of existing research. All authors contributed to writing the paper.

Competing interests. The authors declare that they have no conflict of interest.

Acknowledgements. Chris Huntingford, Rebecca J. Oliver and Lina M. Mercado acknowledge support from the NERC-CEH National Capability Fund. Rebecca J. Oliver and Lina M. Mercado acknowledge support from UK Natural Environment Research Council grant NE/N017951/1. Lina M. Mercado and Stephen Sitch acknowledge support from UK Natural Environment Research Council grant NE/R001812/1

Edited by: Sönke Zaehle

Reviewed by: two anonymous referees

\section{References}

Ainsworth, E. A., Yendrek, C. R., Sitch, S., Collins, W. J., and Emberson, L. D.: The Effects of Tropospheric Ozone on Net Primary Productivity and Implications for Climate Change, Annu. Rev. Plant Biol., 63, 637-661, https://doi.org/10.1146/annurevarplant-042110-103829, 2012.

Anav, A., Menut, L., Khvorostyanov, D., and Viovy, N.: Impact of tropospheric ozone on the Euro-Mediterranean vegetation, Glob. Change Biol., 17, 2342-2359, https://doi.org/10.1111/j.13652486.2010.02387.x, 2011.

Avnery, S., Mauzerall, D. L., Liu, J., and Horowitz, L. W.: Global crop yield reductions due to surface ozone exposure: 1. Year 2000 crop production losses and economic damage, Atmos. Environ., 45, 2284-2296, https://doi.org/10.1016/j.atmosenv.2010.11.045, 2011.

Clark, D. B., Mercado, L. M., Sitch, S., Jones, C. D., Gedney, N., Best, M. J., Pryor, M., Rooney, G. G., Essery, R. L. H., Blyth, E., Boucher, O., Harding, R. J., Huntingford, C., and Cox, P. M.: The Joint UK Land Environment Simulator (JULES), model description - Part 2: Carbon fluxes and vegetation dynamics, Geosci. Model Dev., 4, 701-722, https://doi.org/10.5194/gmd-4701-2011, 2011.

Felzer, B., Reilly, J., Melillo, J., Kicklighter, D., Sarofim, M., Wang, C., Prinn, R., and Zhuang, Q.: Future effects of ozone on carbon sequestration and climate change policy using a global biogeochemical model, Climatic Change, 73, 345-373, https://doi.org/10.1007/s10584-005-6776-4, 2005.

Franz, M., Simpson, D., Arneth, A., and Zaehle, S.: Development and evaluation of an ozone deposition scheme for coupling to a terrestrial biosphere model, Biogeosciences, 14, 4571, https://doi.org/10.5194/bg-14-45-2017, 2017.

Grulke, N. E., Neufeld, H. S., Davison, A. W., Roberts, M., and Chappelka, A. H.: Stomatal behavior of ozone-sensitive and -insensitive coneflowers (Rudbeckia laciniata var. digitata) in
Great Smoky Mountains National Park, New Phytol., 173, 100109, https://doi.org/10.1111/j.1469-8137.2006.01872.x, 2007.

Harper, A. B., Cox, P. M., Friedlingstein, P., Wiltshire, A. J., Jones, C. D., Sitch, S., Mercado, L. M., Groenendijk, M., Robertson, E., Kattge, J., Bönisch, G., Atkin, O. K., Bahn, M., Cornelissen, J., Niinemets, Ü., Onipchenko, V., Peñuelas, J., Poorter, L., Reich, P. B., Soudzilovskaia, N. A., and Bodegom, P. V.: Improved representation of plant functional types and physiology in the Joint UK Land Environment Simulator (JULES v4.2) using plant trait information, Geosci. Model Dev., 9, 2415-2440, https://doi.org/10.5194/gmd-9-2415-2016, 2016.

Hayes, F., Wagg, S., Mills, G., Wilkinson, S., and Davies, W.: Ozone effects in a drier climate: implications for stomatal fluxes of reduced stomatal sensitivity to soil drying in a typical grassland species, Glob. Change Biol., 18, 948-959, https://doi.org/10.1111/j.1365-2486.2011.02613.x, 2012.

Hoshika, Y., Omasa, K., and Paoletti, E.: Whole-Tree Water Use Efficiency Is Decreased by Ambient Ozone and Not Affected by O-3-Induced Stomatal Sluggishness, PLOS ONE, 7, e39270, https://doi.org/10.1371/journal.pone.0039270, 2012a.

Hoshika, Y., Watanabe, M., Inada, N., and Koike, T.: Ozoneinduced stomatal sluggishness develops progressively in Siebold's beech (Fagus crenata), Environ. Pollut., 166, 152-156, https://doi.org/10.1016/j.envpol.2012.03.013, 2012b.

Hoshika, Y., Katata, G., Deushi, M., Watanabe, M., Koike, T., and Paoletti, E.: Ozone-induced stomatal sluggishness changes carbon and water balance of temperate deciduous forests, Sci. Rep.UK, 5, 9871, https://doi.org/10.1038/srep09871, 2015.

Hoshika, Y., Watanabe, M., Carrari, E., Paoletti, E., and Koike, T.: Ozone-induced stomatal sluggishness changes stomatal parameters of Jarvis-type model in white birch and deciduous oak, Plant Biol., 20, 20-28, https://doi.org/10.1111/plb.12632, 2018.

Huntingford, C. and Mercado, L. M.: High chance that current atmospheric greenhouse concentrations commit to warmings greater than 1.5 degrees C over land, Sci. Rep.-UK, 6, 30294, https://doi.org/10.1038/srep30294, 2016.

Huntingford, C., Lowe, J. A., Booth, B. B. B., Jones, C. D., Harris, G. R., Gohar, L. K., and Meir, P.: Contributions of carbon cycle uncertainty to future climate projection spread, Tellus B, 61, 355-360, https://doi.org/10.1111/j.1600-0889.2009.00414.x, 2009.

Huntingford, C., Cox, P. M., Mercado, L. M., Sitch, S., Bellouin, N., Boucher, O., and Gedney, N.: Highly contrasting effects of different climate forcing agents on terrestrial ecosystem services, Philos. T. R. Soc. A, 369, 2026-2037, https://doi.org/10.1098/rsta.2010.0314, 2011.

Huntingford, C., Smith, D. M., Davies, W. J., Falk, R., Sitch, S., and Mercado, L. M.: Combining the [ABA] and net photosynthesisbased model equations of stomatal conductance, Ecol. Model., 300, 81-88, https://doi.org/10.1016/j.ecolmodel.2015.01.005, 2015.

IPCC: Climate Change 2013: The Physical Science Basis. Contribution of Working Group I to the Fifth Assessment Report of the Intergovernmental Panel on Climate Change, Cambridge University Press, Cambridge, UK and New York, NY, USA, https://doi.org/10.1017/CBO9781107415324, 2013.

Jones, C. D., Hughes, J. K., Bellouin, N., Hardiman, S. C., Jones, G. S., Knight, J., Liddicoat, S., O'Connor, F. M., Andres, R. J., Bell, C., Boo, K.-O., Bozzo, A., Butchart, N., Cadule, P., 
Corbin, K. D., Doutriaux-Boucher, M., Friedlingstein, P., Gornall, J., Gray, L., Halloran, P. R., Hurtt, G., Ingram, W. J., Lamarque, J.-F., Law, R. M., Meinshausen, M., Osprey, S., Palin, E. J., Parsons Chini, L., Raddatz, T., Sanderson, M. G., Sellar, A. A., Schurer, A., Valdes, P., Wood, N., Woodward, S., Yoshioka, M., and Zerroukat, M.: The HadGEM2-ES implementation of CMIP5 centennial simulations, Geosci. Model Dev., 4, 543-570, https://doi.org/10.5194/gmd-4-543-2011, 2011.

Le Quéré, C., Andrew, R. M., Friedlingstein, P., Sitch, S., Pongratz, J., Manning, A. C., Korsbakken, J. I., Peters, G. P., Canadell, J. G., Jackson, R. B., Boden, T. A., Tans, P. P., Andrews, O. D., Arora, V. K., Bakker, D. C. E., Barbero, L., Becker, M., Betts, R. A., Bopp, L., Chevallier, F., Chini, L. P., Ciais, P., Cosca, C. E., Cross, J., Currie, K., Gasser, T., Harris, I., Hauck, J., Haverd, V., Houghton, R. A., Hunt, C. W., Hurtt, G., Ilyina, T., Jain, A. K., Kato, E., Kautz, M., Keeling, R. F., Klein Goldewijk, K., Körtzinger, A., Landschützer, P., Lefèvre, N., Lenton, A., Lienert, S., Lima, I., Lombardozzi, D., Metzl, N., Millero, F., Monteiro, P. M. S., Munro, D. R., Nabel, J. E. M. S., Nakaoka, S.-I., Nojiri, Y., Padin, X. A., Peregon, A., Pfeil, B., Pierrot, D., Poulter, B., Rehder, G., Reimer, J., Rödenbeck, C., Schwinger, J., Séférian, R., Skjelvan, I., Stocker, B. D., Tian, H., Tilbrook, B., Tubiello, F. N., van der Laan-Luijkx, I. T., van der Werf, G. R., van Heuven, S., Viovy, N., Vuichard, N., Walker, A. P., Watson, A. J., Wiltshire, A. J., Zaehle, S., and Zhu, D.: Global Carbon Budget 2017, Earth Syst. Sci. Data, 10, 405-448, https://doi.org/10.5194/essd-10-405-2018, 2018.

Lombardozzi, D., Levis, S., Bonan, G., and Sparks, J. P.: Predicting photosynthesis and transpiration responses to ozone: decoupling modeled photosynthesis and stomatal conductance, Biogeosciences, 9, 3113-3130, https://doi.org/10.5194/bg-9-31132012, 2012.

Lombardozzi, D., Levis, S., Bonan, G., Hess, P. G., and Sparks, J. P.: The Influence of Chronic Ozone Exposure on Global Carbon and Water Cycles, J. Climate, 28, 292-305, https://doi.org/10.1175/JCLI-D-14-00223.1, 2015.

McLaughlin, S. B., Nosal, M., Wullschleger, S. D., and Sun, G.: Interactive effects of ozone and climate on tree growth and water use in a southern Appalachian forest in the USA, New Phytol., 174, 109-124, https://doi.org/10.1111/j.14698137.2007.02018.x, 2007a.

McLaughlin, S. B., Wullschleger, S. D., Sun, G., and Nosal, M.: Interactive effects of ozone and climate on water use, soil moisture content and streamflow in a southern Appalachian forest in the USA, New Phytol., 174, 125-136, https://doi.org/10.1111/j.1469-8137.2007.01970.x, 2007b.

Mills, G., Hayes, F., Wilkinson, S., and Davies, W. J.: Chronic exposure to increasing background ozone impairs stomatal functioning in grassland species, Glob. Change Biol., 15, 1522-1533, https://doi.org/10.1111/j.1365-2486.2008.01798.x, 2009.

Mills, G., Harmens, H., Wagg, S., Sharps, K., Hayes, F., Fowler, D., Sutton, M., and Davies, B.: Ozone impacts on vegetation in a nitrogen enriched and changing climate, Environ. Pollut., 208, 898-908, https://doi.org/10.1016/j.envpol.2015.09.038, 2016.

Paoletti, E. and Grulke, N. E.: Ozone exposure and stomatal sluggishness in different plant physiognomic classes, Environ. Pollut., 158, 2664-2671, https://doi.org/10.1016/j.envpol.2010.04.024, 2010.
Sitch, S., Cox, P. M., Collins, W. J., and Huntingford, C.: Indirect radiative forcing of climate change through ozone effects on the land-carbon sink, Nature, 448, 791-794, https://doi.org/10.1038/nature06059, 2007.

Sun, G., McLaughlin, S. B., Porter, J. H., Uddling, J., Mulholland, P. J., Adams, M. B., and Pederson, N.: Interactive influences of ozone and climate on streamflow of forested watersheds, Glob. Change Biol., 18, 3395-3409, https://doi.org/10.1111/j.13652486.2012.02787.x, 2012.

Tai, A. P. K., Martin, M. V., and Heald, C. L.: Threat to future global food security from climate change and ozone air pollution, Nat. Clim. Change, 4, 817-821, https://doi.org/10.1038/NCLIMATE2317, 2014.

Taylor, K. E., Stouffer, R. J., and Meehl, G. A.: An Overview of CMIP5 and the Experiment Design, B. Am. Meteorol. Soc., 93, 485-498, https://doi.org/10.1175/BAMS-D-11-00094.1, 2012.

Van Dingenen, R., Dentener, F. J., Raes, F., Krol, M. C., Emberson, L., and Cofala, J.: The global impact of ozone on agricultural crop yields under current and future air quality legislation, Atmos. Environ., 43, 604-618, https://doi.org/10.1016/j.atmosenv.2008.10.033, 2009.

Vingarzan, R.: A review of surface ozone background levels and trends, Atmos. Environ., 38, 3431-3442, https://doi.org/10.1016/j.atmosenv.2004.03.030, 2004.

Wagg, S., Mills, G., Hayes, F., Wilkinson, S., and Davies, W. J.: Stomata are less responsive to environmental stimuli in high background ozone in Dactylis glomerata and Ranunculus acris, Environ. Pollut., 175, 82-91, https://doi.org/10.1016/j.envpol.2012.11.027, 2013.

Wilkinson, S. and Davies, W. J.: Ozone suppresses soil dryingand abscisic acid (ABA)-induced stomatal closure via an ethylene-dependent mechanism, Plant Cell Environ., 32, 949959, https://doi.org/10.1111/j.1365-3040.2009.01970.x, 2009.

Wilkinson, S. and Davies, W. J.: Drought, ozone, ABA and ethylene: new insights from cell to plant to community, Plant Cell Environ., 33, 510-525, https://doi.org/10.1111/j.13653040.2009.02052.x, 2010.

Wittig, V. E., Ainsworth, E. A., and Long, S. P.: To what extent do current and projected increases in surface ozone affect photosynthesis and stomatal conductance of trees? A metaanalytic review of the last 3 decades of experiments, Plant Cell Environ., 30, 1150-1162, https://doi.org/10.1111/j.13653040.2007.01717.x, 2007.

Wittig, V. E., Ainsworth, E. A., Naidu, S. L., Karnosky, D. F., and Long, S. P.: Quantifying the impact of current and future tropospheric ozone on tree biomass, growth, physiology and biochemistry: a quantitative meta-analysis, Glob. Change Biol., 15, 396424, https://doi.org/10.1111/j.1365-2486.2008.01774.x, 2009.

Zaehle, S. and Friend, A. D.: Carbon and nitrogen cycle dynamics in the O-CN land surface model: 1. Model description, site-scale evaluation, and sensitivity to parameter estimates, Global Biogeochem. Cy., 24, GB1005, https://doi.org/10.1029/2009GB003521, 2010. 